\title{
Teachers' Views of the Implementation of STEM Approach in Secondary Schools and The Effects on Students
}

\author{
Cevdet Tunc $^{1 *}$, Birsen Bagceci ${ }^{2}$
}

${ }^{1}$ Bolu Abant İzzet Baysal University, TURKEY

${ }^{2}$ Gaziantep University, TURKEY

*Corresponding Author: cevdettunc@hotmail.com

Citation: Tunc, C., \& Bagceci, B. (2021). Teachers' Views of the Implementation of STEM Approach in Secondary Schools and The Effects on Students. Pedagogical Research, 6(1), em0085. https://doi.org/10.29333/pr/9295

\begin{tabular}{|c|c|}
\hline ARTICLE INFO & ABSTRACT \\
\hline Received: 25 Oct. 2020 & STEM (Science, Technology, Engineering and Mathematics) approach is considered important by many countries \\
\hline Accepted: 3 Nov. 2020 & $\begin{array}{l}\text { and projects carried out in order to integrate into their curriculum. The widespread use of STEM is only possible if } \\
\text { teachers have positive thoughts, knowledge and experiences about it. In this study, it is aimed to answer these } \\
\text { research questions: "What do teachers think about the gains their students will achieve if STEM activities are } \\
\text { implemented to their students?" and "What do they think about the implementation of STEM approach in their } \\
\text { schools?". This study is a case study. Participants are twenty-three mathematics, science and information and } \\
\text { communication technologies teachers (ICT). "Activities Evaluation Form" and "STEM Training In-School } \\
\text { Implementation Evaluation Questionnaire" were used as data collection tools. As a result of research, although } \\
\text { teachers have hesitations about implementing STEM activities in classrooms; they think that these } \\
\text { implementations will make a significant contribution to students about the "skills" students will acquire, the } \\
\text { dimension of knowledge they will gain about STEM activities, and the acquisitions of students regarding the } \\
\text { learning process. }\end{array}$ \\
\hline
\end{tabular}

Keywords: STEM approach, integrated teaching framework, STEM classroom activities

\section{INTRODUCTION}

In today's world, there is a need for individuals with 21st-century skills such as critical thinking, entrepreneurship, communication, collaboration, decision-making, leadership, problem-solving, responsibility, and creativity. One of the educational approaches in which these individuals are nourished is the STEM approach (Ergün \& Külekci, 2019; Siregar et al., 2019). STEM was first mentioned by The National Science Foundation director J. A. Ramaley in 2001 and spread rapidly after this date (Yıldırım \& Altun, 2015). STEM is an education term consisting of the initials of science, technology, engineering and mathematics. Although STEM approach basically consists of the four main components mentioned above, the Art component has been added to these disciplines in recent literature studies, and it has been added to the literature as a new approach with the abbreviation STEAM or STEM + A. According to Land (2013), while the focus of the traditional STEM approach is the development of analytical thinking skills, both analytical and creative thinking skills come to the fore in STEM + A education approach. Another STEM approach is the one that has taken place in the literature with the abbreviation CT-STEM. In this approach, the authentic structure of STEM and "Computational Thinking" were handled in an integrated manner and the CT-STEM approach was classified with a taxonomic structure (Weintrop et al., 2016). In recent years, entrepreneurship in STEM approach has become one of the fields that are integrated with STEM approach as a separate component and it has been included in the literature with the abbreviation STEM $+\mathrm{E}$.

In contemporary times, the importance of ensuring students with a strong education in science, technology, engineering and mathematics (STEM) has been emphasized (Thibaut et al., 2018). Teaching approaches related to STEM are now considered as one of the most emerging areas in the context of education in both developed and developing countries (Madani, 2020). Economically developed countries such as the USA, England, and Japan felt the need to invest in STEM education-related fields for the future. These countries carry out many implementations for STEM in governmental and non-governmental organizations, scientific institutions, universities, and schools.

Teachers' role is inevitable in the easy adaptation of innovations such as STEM to the education system and in overcoming the problems encountered. Teachers' perceptions and preparedness really affect the success of the implementation of STEM 
education. They need to have adequate prior training and understanding in order to teach STEM activities to their students. However, teachers' perceptions and beliefs that form their approaches and methodologies for the implementation of new educational reform are usually disregarded (Madani, 2020).

The main purpose of this study is to determine the opinions of teachers participating in STEM education on the implementation of STEM in their own classrooms and what kind of impression will it have on their students. Research questions in this context:

1- What do teachers think about the gains their students will achieve if STEM activities are implemented to their students?

2- What do they think about the implementation of STEM approach in their classrooms?

\section{LITERATURE REVIEW}

STEM, is an educational approach that addresses all student levels from pre-school education to university, which includes teaching the disciplines of science, technology, engineering and mathematics in an integrated manner. This education approach is of great importance in terms of transforming theoretical knowledge into practice and creating an environment for design and product development.

In our age, institutions and organizations expect individuals to be productive, so individuals need to have competence in many areas and also have practical skills in the field of engineering (Siew et al., 2015). The emphasis of the STEM approach, especially on technology and engineering disciplines, provides students with an interdisciplinary perspective from an early age, gives the opportunity to put theoretical knowledge into practice, and enables it to be implemented, giving it a very important place in the age of information technologies and communication (Akgündüz et al., 2015; Smyrnova-trybulska et al., 2016).

The implementations of STEM learning activities could combine science, technology, engineering, and mathematics as well as nurture students' problem-solving skills so that students can place thinking and exploration in a central part of their lives (Gunawan \& Shieh, 2020). Although the in-class implementation methods of STEM education show some differences, a process is followed in which gains from more than one discipline are given together, basically starting from an interdisciplinary approach. In the STEM approach, one of the four main disciplines is placed at the focus and the other three disciplines are used as supporting subjects. In the next step, lesson plans are created. "Authentic Problems of Knowledge Society (APKS)" is kept central of the plans that are created by taking student achievements into account. The lesson plans of APKS, which are shaped over a scenario aimed at solving the problems involving a section of real life, are prepared with materials suitable for the student level and are implemented to the students in the classroom (Aşık et al., 2017; Bayazit et al., 2018; Çorlu et al., 2014; English, 2016; Yıldırım \& Altun, 2015). The teacher guides the students during the course process and gives them the opportunity to socialize.

In today's world where the Industry 4.0 move is rapidly taking place, smart homes, smart factories, industrial robots, areas where artificial intelligence is used, and the internet of objects have started to take a large place in our lives. In this respect, the need for individuals with 21st-century skills, who can think, design, produce, adapt, query, communicate, analyze and solve extraordinary problems, manage and develop themselves, who can implement themselves systematic and creative thinking in the fields of science, technology, mathematics, and engineering (Bybee, 2010; Windschitl, 2009).

According to the results of the study titled "STEM Education and Its Reflections on Field Teacher Education" conducted by Çorlu et al. (2014); Turkey's competitiveness on an international scale as STEM in many countries has strategic importance to be retained. There are intense criticisms that our teachers, who are expected to train the manpower to specialize in these fields, are not trained in accordance with the requirements of the age. In the research, it is aimed to introduce STEM approach within a theoretical framework. For this purpose, ongoing education reform initiatives and researches conducted in Turkey and in the world in the fields of integrated curriculum and teaching knowledge were examined. When focusing on the interaction between science and mathematics, which is an output of the conceptualized model, it was concluded that teachers in Turkey only having the knowledge of teaching in their field of expertise would not be sufficient to train the manpower that Turkey's needs (Çorlu et al., 2014).

In many studies, STEM approach nourishes students' social skills as well as academic success. For example, the findings of the study (Şahin et al., 2014) showed that STEM-related after-school activities have the potential to contribute to the development of 21st-century skills for independent and collaborative scientific research. According to another study (Cotabish et al., 2013) there is a statistically significant difference in science content, concept knowledge and scientific process skills by the primary school students in the experimental group compared to the students in the control group. In addition, teacher participation in the STEM program had a statistically significant effect on the variability of students' final scores. In a study conducted by Wyss et al. (2012), the change in middle school students' interest in STEM education was followed. The findings revealed significant differences in favor of the experimental group. Although the interest of middle school students was positively affected by this situation and their interest in STEM increased as a result of STEM professionals informing students about their potential career through videos, it is seen that the changes in attitude were not deliberately addressed in the study.

After-school program activities related to STEM helped students to develop and use 21st-century skills such as complex communication and collaboration (Jerald, 2009; Levy \& Murnane, 2004). However, the study findings could shed light on the positive effects of the potential features of after-school programs - in terms of students' interest in STEM and their learning gains. After-school activities can have an important contribution to the acquisition of competitiveness, collaborative working, and sharing skills - which are the skills of the century Şahin et al. (2014). 
There are also studies in which teachers' opinions are determined regarding the STEM approach, which has a positive effect on students at different educational levels. The teachers believe that STEM could lead to students learning science in ways that exhilarate them, which in turn could nurture their interest, motivation and attention in science-related topics. Teachers believed that STEM would not only allow students to gain science content but it could also in providing an avenue for them to express their creative ideas. Teachers care about the interdisciplinary nature of STEM projects (Siew et al., 2015).

As a result of study conducted by Bayazit et al. (2018), it was observed that teachers generally gave positive opinions about the activity. They thought the activity was intriguing, economical, fun, interdisciplinary, suitable for teamwork, and reinforcing engineering skills. In addition, considering that teachers from different branches thought that they could highlight the concepts they want to emphasize by making small changes in the activity, it can be suggested to use the "Edible Cars" activity in STEM field lessons or extracurricular activities.

In the study conducted by Akdağ and Güneş (2017), which included the opinions of Science High School students and teachers about STEM implementations on energy, it was determined that STEM implementations contributed to students' learning. It was determined that the students had the opportunity to use their knowledge more actively in the process. The limitation of the implementation process with the course hours was determined as the biggest negativity. It has been concluded that it would be more beneficial to spread the implementations in different units over a wide period.

\section{Integrated Teaching Framework}

STEM approach is shaped as a result of the interests and life experiences of students and teachers. It is defined as teaching the special knowledge and skills of the discipline in the center by integrating with at least one other STEM discipline (Çorlu et al., 2014). STEM: Integrated Teaching Framework is a theoretical roadmap for STEM teaching developed based on different information and data sources. The theoretical framework, which includes a "Authentic Problems of Knowledge Society (APKS) " focusing on complex and dynamic problems, shows the four disciplines, cognitive processes, outputs, and principles, respectively, which also constitute the word meaning of STEM. The integrated teaching framework has a structure consisting of nested rings. APKS builds the center of the framework. Then four disciplines: science, technology, engineering and mathematics (STEM) cover APKS. Four cognitive process methods: inquiry, mathematical modeling, project-based learning and computational thinking build the outer ring. Four social products: flexible curriculums, professional learning community, school-public connection, Theory-practice connection cover the cognitive process methods. In the outermost ring of the framework there are four principles: equity, relevance, rigor and interdisciplinarity (Çorlu, 2017).

\section{METHODOLOGY}

This study is a case study. Case study research is an investigation that focuses on describing, understanding, forecasting, and/or controlling the individual (i.e., process, animal, person, household, organization, group, industry, culture, or nationality) (Woodside, 2010). STEM training prepared for secondary school teachers was chosen as a case study. Qualitative data sources were used to determine the participants' opinions on the training contents and its effect on the students.

\section{Study Group}

Secondary school teachers working in Gaziantep Province were selected as the study group. During the teacher selection process, an application was made through the official website of the Gaziantep Provincial Directorate of National Education. A total of 35 teachers, including 25 full and 10 substitute teachers, were selected among approximately 270 teachers who applied.

While choosing teachers, priority was given to teachers who meet the conditions pre-determined by the project team. These conditions are:

- 0-7 years of professional experience,

- Attending classes in mathematics, science and information and communication Technologies branches,

- Working in public schools,

- Teaching classes in 5 th and 6 th grades.

Since two teachers could not attend the training, it was conducted with twenty-three teachers. Nine of the participants are male and fourteen of them are female. Age range is 23-38. Eight of them are from mathematics, ten are from science, and five are from information and communication technologies (ICT). All teachers have 0-7 years of experience, of which eleven have 0-3 years and the remaining twelve have 4-7 years of experience. It has been determined that all teachers have graduated from the Education Faculties of different universities. In addition, four teachers had received STEM education before.

\section{Implementation of Training}

A four-day training has been developed for teachers to gain competencies related to STEM. In the in-service training development process, firstly a needs analysis was made and then the outcomes were determined. Later, the contents were developed. Implementations used in in-service training are given below. Since the development process of in-service training was not the scope of this study, the study (Tunç, 2019) can be examined for detailed information. 
Table 1. Explanation Regarding STEM Training Lesson Plans

\begin{tabular}{|c|c|c|c|c|}
\hline STEM Lesson Plan & 1.Day & 2. Day & 3. Day & 4. Day \\
\hline Project Name & $\begin{array}{l}\text { Calculating the Surface Area } \\
\text { and Volume of a Room with } \\
\text { the Help of Sound Waves }\end{array}$ & $\begin{array}{l}\text { Calculation of Correct Tilt } \\
\text { Angle According to the } \\
\text { Geographical Conditions of } \\
\text { Gaziantep Province to } \\
\text { Maximize the Efficiency of } \\
\text { Solar Panels }\end{array}$ & $\begin{array}{l}\text { Designing a Smart Robot Car } \\
\text { with Arduino }\end{array}$ & $\begin{array}{l}\text { Designing a Catapult using } \\
\text { the K'nex Training Kit }\end{array}$ \\
\hline $\begin{array}{l}\text { APKS (Authentic } \\
\text { Problems of } \\
\text { Knowledge Society) }\end{array}$ & $\begin{array}{l}\text { You are implementing for a } \\
\text { job with an engineering firm. } \\
\text { The board that conducted } \\
\text { the interview asks you a } \\
\text { question. "How would you } \\
\text { make a design that } \\
\text { calculates the volume of } \\
\text { your room with sound } \\
\text { waves?" What kind of a } \\
\text { design would you give the } \\
\text { most appropriate answer to } \\
\text { this question? }\end{array}$ & $\begin{array}{l}\text { You are responsible for } \\
\text { installing solar power plants in } \\
\text { alternative energy company. } \\
\text { Your company assigns you to } \\
\text { establish a solar power plant } \\
\text { in Gaziantep University. Your } \\
\text { task is to find the angle of } \\
\text { inclination that will get the } \\
\text { best efficiency in solar panels } \\
\text { and place the panels with the } \\
\text { ideal slope. }\end{array}$ & $\begin{array}{l}\text { Google company is organizing a } \\
\text { competition. The aim of the } \\
\text { competition is to design a smart } \\
\text { robot car that changes direction } \\
\text { without getting caught in the } \\
\text { obstacle. This car must be the } \\
\text { car that hits the least number of } \\
\text { obstacles in } 3 \text { minutes, travels } 15 \\
\text { meters fastest and has the best } \\
\text { exterior design. You are also an } \\
\text { engineer participating in this } \\
\text { competition. Design the most } \\
\text { suitable car for this competition. }\end{array}$ & $\begin{array}{l}\text { You work as a project } \\
\text { manager in a playground. } \\
\text { In the playground, you are } \\
\text { asked to set up an } \\
\text { amusement stand for } \\
\text { shooting baskets and } \\
\text { winning a teddy bear with } \\
\text { an adjustable angle } \\
\text { catapult. Make the most } \\
\text { appropriate design. }\end{array}$ \\
\hline Grade level & $5^{\text {th }}$ grade & $5^{\text {th }}$ grade & $6^{\text {th }}$ grade & $6^{\text {th }}$ grade \\
\hline Central Discipline & Mathematics & Science & Engineering & Technology \\
\hline $\begin{array}{l}\text { Supportive } \\
\text { Discipline }\end{array}$ & Science & $\begin{array}{l}\text { Mathematics Engineering } \\
\text { Technology }\end{array}$ & $\begin{array}{l}\text { Mathematics Science } \\
\text { Technology }\end{array}$ & Science \\
\hline Materials & $\begin{array}{l}\text { - Arduino Uno, } \\
\text {-Ultrasonic distance sensor, } \\
\text { - Balsa tree, } \\
\text {-Stationery material, } \\
\text { Jumper cable, } \\
\text { - Breadboard, } \\
\text { LCD screen, } \\
\text { LM35 Heat sensor, } \\
\text { - Data shield }\end{array}$ & $\begin{array}{l}\text {-Solar panels, } \\
\text { - K'nex bars and connectors, } \\
\text { Led and cables, } \\
\text { Potentiometer, } \\
\text { - Pyrometer, } \\
\text { Cardboard, scissors, set } \\
\text { square, } \\
\text {-Aluminum foil, } \\
\text { DC motor, } \\
\text { - Soldering Machine, } \\
\text { - Solder wire and paste, }\end{array}$ & $\begin{array}{l}\text { Bluetooth car kit, } \\
\text { - Arduino Uno, } \\
\text { - Ultrasonic distance sensor, } \\
\text { - Motor driver card, } \\
\text { Bluetooth module, } \\
\text { Jumper cables, } \\
\text {-Stationery, } \\
\text { - Data shield. } \\
\text { On off switch, } \\
\text { - Mini breadboard, }\end{array}$ & $\begin{array}{l}\text {-K 'nex model } 70 \\
\text { - Money tire, } \\
\text { Glass bead, } \\
\text { - Ruler, } \\
\text { - Miter, } \\
\text {-Stationery material, }\end{array}$ \\
\hline Designed Product & Ultrasonic distance meter & Solar power plant & $\begin{array}{l}\text { Bluetooth RC and autonomous } \\
\text { car }\end{array}$ & $\begin{array}{l}\text { Entertainment stand } \\
\text { catapult design }\end{array}$ \\
\hline
\end{tabular}

\section{STEM education implementations}

Four STEM lesson plans to be used in education have been prepared such that there will be a central discipline every day and at least one of the other disciplines will be a supportive discipline in accordance with the integrated structure of STEM education. While preparing these plans, the annual plans and programs of the Ministry of Education, 5th and 6th grades science, mathematics, and information and communication technologies for the 2016-2017 academic year were examined and outcome lists were created that can be used while creating the STEM Lesson Plan. These plans are briefly mentioned in Table 1.

Five educators guided these trainings. Participating teachers were separated into five teams of 4-5 people, and care was taken to have mathematics, science and information and communication technologies (ICT) teachers in each team.

\section{Data Collection Tools}

Two different data collection tools were used to achieve teachers' opinions.

\section{Activities evaluation form}

This is a qualitative data collection tool that consists of three open-ended questions and it is used to evaluate the activity of each day. An expert review was consulted to ensure the validity of the form. First of all, the form items prepared were sent to the experts (two STEM experts and two educational sciences experts) separately. The questions were asked to evaluate the degree of serving the purpose and understandability by the teachers. After the feedback received from experts was positive, it was examined by an assessment and evaluation specialist. The data were analyzed using a package program. In this study, "If you implemented this activity in the classroom, what kind of outcomes would you think the students meet?" is used to answer the research question.

\section{STEM training in-school implementation evaluation questionnaire}

Materials support was provided to ten teachers for teachers to implement STEM in school. During the 2017-2018 academic year, teachers were mentored, and this evaluation questionnaire consisting of semi-structured questions (See Appendix 1) was implemented in June 2018. An expert review technique was consulted for the validity of each data collection tool. Two STEM experts and two educational science experts reviewed the questionnaire. 
Table 2. The Effect of STEM Implementations on Students Skill Category

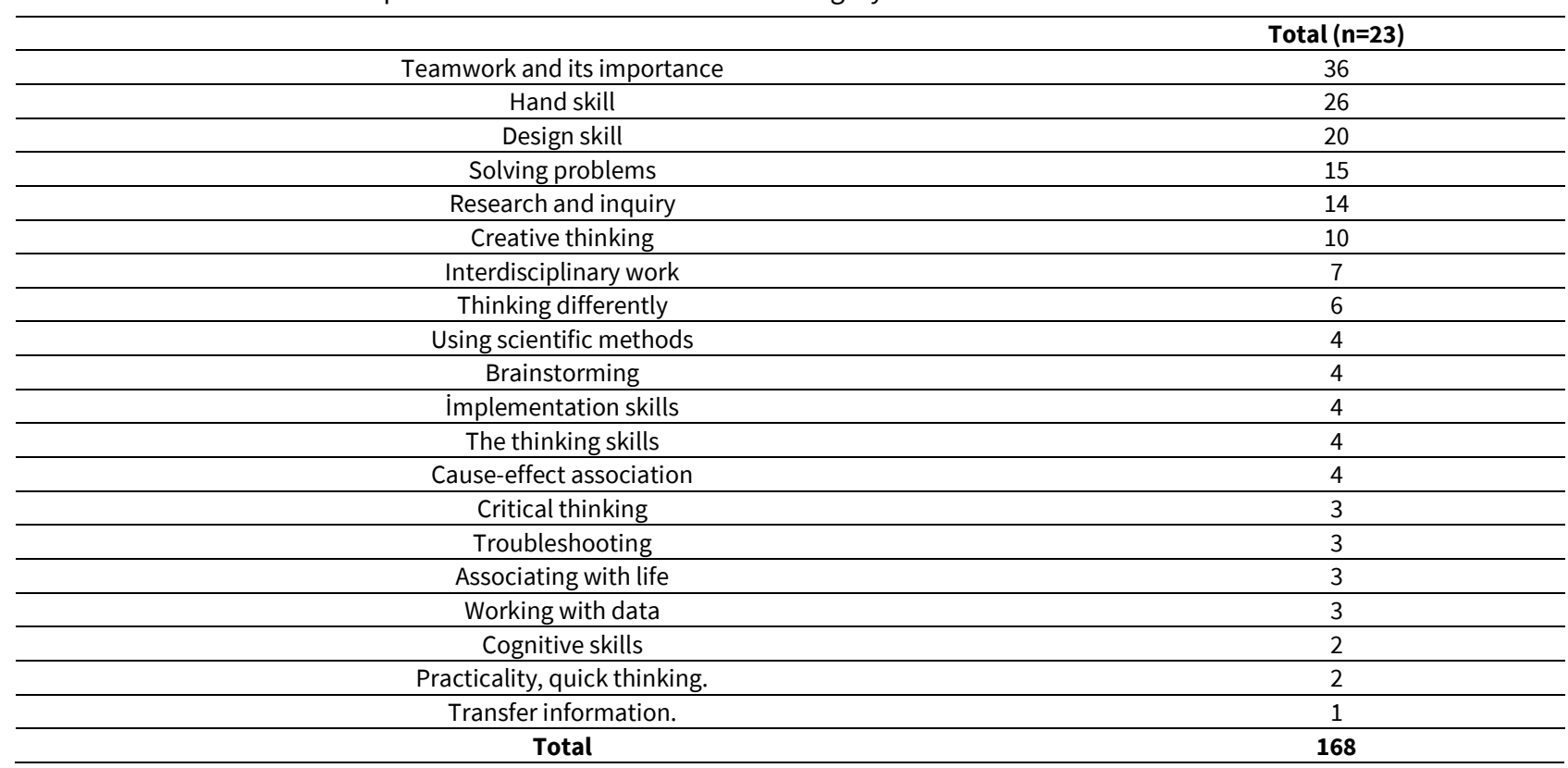

\section{Data Analysis}

The content analysis approach was preferred among qualitative research techniques. As a general approach, firstly, the statements written/spoken by the participants were freely coded. The data were re-coded six weeks later and the final coding was reviewed with STEM and educational sciences field experts. Categories and themes were obtained by combining codes according to their similarity. In the activities evaluation forms, 308 codes were determined for first period and 296 for second period. Code reliability is calculated as $(296 / 308=\% 96)$. For the school implementation evaluation questionnaire, the number of codes in first period and second period are the same, so the code reliability is accepted as $\% 100$.

A total of seven categories were formed in the school implementation form analyses. When listed according to the multiplicity of the codes in the categories, there are eleven codes for "the reason for not implementing" (Table 6). The category "the problems encountered in the implementation" (Table 5) has seven codes, "other problems" (Table 9) has five, "the potential problems" (Table 8) has four, "the implementation completion" has two codes, "the implementation of STEM Training" (Table 7) has three and "the implementation examples" has only one code.

In the analysis of the activities evaluation forms, seventeen codes were produced under the title of skill category. A total of four categories were formed under the theme of the knowledge dimension. When sorted according to the multiplicity of the codes in the categories, there are thirteen codes on the use of tools and equipment, eight codes on the project subject, four codes in the other category, and two codes in the last category. There are four codes out of the category. In the analysis of the second question of the activities evaluation form, a total of three categories were formed. There are twenty codes in the skill dimension (Table 2), seventeen in the knowledge dimension (Table 3), and eleven in the learning-teaching process dimension when sorted according to the multiplicity of the codes in the categories. In the analysis of the third question, a total of two categories were formed. While there are ten codes in the skill dimension, there are five codes in the other achievements (Table 4).

\section{FINDINGS}

Within the scope of the implementation of STEM in schools, first of all, teachers' opinions were presented on what the gains of STEM activities could be for students. In the second part, teachers' thoughts on the integration of STEM into the curriculum are given.

\section{The View about the Effect of STEM Implementations on Students}

The data related to possible effects of STEM implementations on students was gathered from "Activities Evaluation Form". The first question taken into consideration was, "If you implemented this activity in the classroom, what kind of outcomes would you think the students meet?" The analysis of the answers given to the question is presented.

Table 2 contains the codes in the skill category of the findings obtained from the activities end-of-day evaluation forms. When these codes are examined, teamwork and its importance, hand skills, and design skills have come to the fore regarding the achievements that students can obtain. In addition to these, it is stated that creative thinking skills will also improve with problemsolving, research and inquiry. Interdisciplinary work, thinking differently, using scientific methods, brainstorming, implementation skills, thinking skills, and cause-effect association are among the skills to be acquired. When considered in general, teachers stated such gains 168 times. 
Table 3. The Effect of STEM Implementations on Students Knowledge Category

\begin{tabular}{|c|c|}
\hline & Total $(n=23)$ \\
\hline Solar energy and energy conversion & 12 \\
\hline Arduino set usage & 8 \\
\hline Math-computational knowledge & 8 \\
\hline Angle and voltage relationship & 6 \\
\hline Designing with K'nex & 6 \\
\hline Sound Wave & 5 \\
\hline Car design and information & 3 \\
\hline Engineering gains & 3 \\
\hline Using technology & 3 \\
\hline Soldering & 2 \\
\hline Robot making & 2 \\
\hline Learning new materials and knowledge & 2 \\
\hline Simple machine subject gains & 2 \\
\hline Strength gains & 2 \\
\hline The importance of security & 1 \\
\hline The difference between heat and temperature & 1 \\
\hline Understands the weight of matter & 1 \\
\hline Total & 67 \\
\hline
\end{tabular}

Table 4. The Effect of STEM Implementations on Students Learning Process and Other Gains Category

\begin{tabular}{|c|c|}
\hline Learning Process Category & Total $(n=23)$ \\
\hline Social skills & 12 \\
\hline Collaborative learning & 7 \\
\hline Learning by doing & 6 \\
\hline Responsibility & 5 \\
\hline Learning by having fun & 2 \\
\hline Exchange of ideas & 2 \\
\hline Increase in self-confidence & 2 \\
\hline Emotional skills & 1 \\
\hline Arouse curiosity & 1 \\
\hline Don't compete & 1 \\
\hline Subtotal & 38 \\
\hline \multicolumn{2}{|l|}{ Other Gains Category } \\
\hline More students are reached with STEM activities & 2 \\
\hline It will also improve motor skills & 1 \\
\hline The student will learn without realizing the achievements & 1 \\
\hline Increases student motivation & 1 \\
\hline Guides students to basic sciences & 1 \\
\hline Total $(n=23)$ & Total $(n=23)$ \\
\hline
\end{tabular}

When the codes are examined in the knowledge category of the participation, solar energy, energy conversion, use of the Arduino set, and mathematical computational knowledge comes to the fore regarding the gains that students can achieve. In addition, angle and voltage relationships, designing with K'nex, and sound waves are among the possible gains to be learned. In general, it is assumed that students will obtain information about the project in the knowledge category.

When codes are examined in the learning process category of participation, social skills, cooperative learning, learning by doing and responsibility skills come to the fore regarding the achievements that students can achieve. Along with this, it was also stated that students will learn by having fun and exchanging ideas which causes their self-confidence to increase.

Teachers have stated that more students will be reached with STEM activities in the category of STEM students' attainments. They have also stated that students' motor skills would improve, and students would learn without realizing the outcomes. Besides, they think that students' motivation will increase, and they will direct students to basic sciences.

\section{Implementations of STEM at a Secondary School}

Regarding the implementation at school, the "In-School Implementation Evaluation Questionnaire" was used. The analysis of these data is presented below:

Four out of eleven teachers in total stated that they are doing classroom implementations. For the implementation examples, the teacher, whose code name is Fensa, is one of the participants in the STEM training project, stated that: "Firstly, we built the Sun, the Earth and the Moon movements (we created moving models using K'nex parts), and secondly we went to the Moon (We designed spacecraft using waste materials). And thirdly, we created a seismograph that measures earthquake vibrations by using K'nex-Arduino sensors)". A teacher named Mete from the participants; stated that he created the "K'nex bridge" study. The participant teacher, code named Mars, stated that they made "Fast circulation and Formula 1 race". One of the participants, Alchemist shared, "the factor tree was an activity based on prime numbers in the mathematics course and the electrical circuit topics from the science lesson." " getting the right ratio in healthy nutrition is a lesson plan that combines the ratio topic in the mathematics 
Table 5. Problems in the Implementations

\begin{tabular}{cc}
\hline & Problems \\
\hline Problems During the Implementation Process & 2 \\
\hline Time problem & 2 \\
\hline Lack of material & 2 \\
\hline Finding cheap material & 1 \\
\hline Class size & 1 \\
\hline Problems Caused by Students & 1 \\
\hline Spatial Problems & 1 \\
\hline Total & 10 \\
\hline
\end{tabular}

Table 6. Reasons for Teachers Who Cannot Implement the STEM Lesson Plan in the Classroom

\begin{tabular}{cc}
\hline Reasons & Total (n=7) \\
\hline Lack of school infrastructure & 4 \\
\hline Inability to create the appropriate time and environment & 3 \\
\hline Change of duty & 2 \\
\hline Students' readiness level & 2 \\
\hline Large class size & 2 \\
\hline Not being able to attend classes in suitable classes & 2 \\
\hline My busy school schedule & 2 \\
\hline I could not finish the curriculum & \\
\hline Requires serious preparation & 1 \\
\hline Inability to cooperate with other teachers \\
\hline Total \\
\hline
\end{tabular}

Table 7. Implementation Category of STEM Training

\begin{tabular}{cc}
\hline & Total (n=21) \\
\hline Material supply problem & 1 \\
\hline Can be implemented at school & 1 \\
\hline I want to implement & 3 \\
\hline Total & $\mathbf{5}$ \\
\hline
\end{tabular}

Table 8. Potential Problems Theme

\begin{tabular}{cc}
\hline & Total(n=21) \\
\hline I should know other branches as well & 1 \\
\hline I have to do additional work & 1 \\
\hline I have problems with the density & 1 \\
\hline I have to learn to code Arduino & 1 \\
\hline Total & $\mathbf{4}$ \\
\hline
\end{tabular}

course and the nutrients in the science course" and "Nutrient Data; He stated that the mathematics lesson is a lesson plan based on the subject of graphical interpretation and the subject of science nutrients".

When evaluated in general, eleven teachers from the participants provided information about their in-school activities. Only four of these teachers planned activities and only three of them completed activities related to implementations for the classroom.

According to the table, the most encountered problems are lack of material, problems experienced during the implementation process and time problems. Also finding cheap material, class size, problems caused by students and spatial problems are stated by teacher.

Seven out of eleven teachers who gave feedback stated that they could not practice. When the reasons for the teachers who could not practice in Table 6 are examined, the most expressed problem was the lack of school infrastructure. Also, they stated the reasons for not being able to create a suitable time and environment three times. The reasons for the insufficient readiness of the students, not attending classes in the appropriate classes and the intensive school schedule were mentioned twice. In addition, they stated the reasons for requiring serious preparation, not being able to train the program, not being able to cooperate with other teachers, and not being able to find outcomes suitable for STEM in 7th grade. Although it is stated once to be unable to cooperate with other teachers and find outcomes suitable for STEM, it may be an indication that teachers have difficulties in implementing STEM in the field.

When the opinions of teachers on the implementation of STEM were examined, it was stated that they wanted to practice, and it was stated that it could be implemented at school and that they could have a problem with material procurement.

Teachers stated that in the case of implementing projects in their schools, a teacher should know other branches and that he should learn Arduino coding. He also stated that he should do additional work and that he might have problems during school time due to the intensity. 
Table 9. Codes Related to Other Problem Theme

\begin{tabular}{cc}
\hline & Total(n=21) \\
\hline Desire to be continuous & 11 \\
\hline I may have trouble determining the problem & 1 \\
\hline It's nice that the evaluation is a product & 1 \\
\hline Examining the achievements and focusing on mathematics & 1 \\
\hline Associating mathematics with other fields & 1 \\
\hline Total & $\mathbf{1 5}$ \\
\hline
\end{tabular}

When the codes of teachers under the other theme were examined, a teacher stated that it could be difficult to identify a problem and that it was nice to be a product of evaluation. The desire that education should be continuous was also stated as a common thought by the teachers who participated in the focus group discussion.

\section{DISCUSSION}

First of all, teachers were asked what effect STEM activities would have on students if they implemented them in their classrooms. According to the answers obtained from the teachers, three main categories come to the fore. The first of these refers to the "skills" students will acquire. Second, it refers to the dimension of knowledge they will gain about STEM activities. Third, it refers to the acquisitions of students regarding the learning process.

In terms of its effect on students' skills, "teamwork", "hand skill”, "design skill”, "problem-solving skill”, "research and questioning skill" and "Creative thinking" come to the fore. The skills mentioned by teachers overlap with $21^{\text {st }}$-century skills. In many studies (Altan et al., 2018; Jesionkowska et al., 2020; Windschitl, 2009), it has been emphasized that it is important to gain $21^{\text {st }}$-century skills in this school process. After-school program activities related to STEM have helped students develop and use 21st-century skills such as complex communication and collaboration (Bakırcı \& Kutlu, 2018; Changtong et al., 2020; Jerald, 2009; Levy \& Murnane, 2004; Margot \& Kettler, 2019; Siew et al., 2015). Another important concept is creativity. Thanks to STEM projects, students find channels to express their creative ideas (Siew et al., 2015). According to the results of the research (Changtong et al., 2020), students' conceptual understanding of scientific concepts, scientific reasoning skills, and soft skills improve more with STEM activities. As a result of STEM-based robotics activities, teachers stated that students improved in "solving real problems", "critical systems thinking", "communication skills", "effective cooperation", "teamwork skills", "quick search and data processing", and "Ability to take responsibility" (Smyrnova-trybulska et al., 2016).

There are situations where STEM projects are not completed, and sufficient success is not achieved. For example, in this study, one of the teachers could not complete his project. According to a systematic review study conducted by Margot and Kettler (2019), teachers believe that struggle and even failure are inherent yet valuable components of the engineering design process within STEM education.

In terms of knowledge and learning process, it is emphasized that learning the project subjects will also develop social skills, corporate learning, and learning by doing and experiencing. Participants think that STEM implementations will contribute to students' achieving certain outcomes. In the study conducted by Bakırcı and Kutlu (2018), teachers stated that STEM activities provided learning by living, concretizing the subjects, meaningful learning and engineering topics to their students. In some studies (Bakırcı \& Kutlu, 2018; Smyrnova-trybulska et al., 2016), it has been observed that students perceive the learning process in STEM activities more enjoyable, assume learning responsibilities, and have a positive attitude towards learning. The opinions of the teachers and the results of this study are parallel.

Researchers and practitioners face many difficulties while doing STEM activities. In the study conducted by Landicho (2020), the main challenges faced by the participants are lack of financial support, heavy teaching load and work-related tasks, and limited research experience and exposure, and limited funding or financial support. In this study, some difficulties that worry teachers, such as insufficiency of the current course hours, crowded class sizes, high curriculum and acquisition intensity, and difficulty in material procurement and follow-up, are also an undeniable situation. This situation reveals the difficulty of fully implementing the skills and outputs obtained in in-service training. The main problems encountered in practice are the problems experienced during the implementation process, the time problem, and the lack of material. This result is in parallel with other studies (Eroğlu \& Bektaş, 2016; Firat, 2020; Siew et al., 2015) in the literature. According to a systematic review study conducted by Margot and Kettler (2019), teachers identified pedagogical challenges, curriculum challenges, structural challenges, student concerns, assessments, time, and knowledge, as barriers to using STEM pedagogy in their classrooms.

The reasons for teachers who cannot practice come to the fore due to the lack of infrastructure, not being able to arrange the appropriate time and environment. When the findings are evaluated, in order for STEM education to be implemented in school, it is necessary to prepare the school infrastructure as well as the skills of the teachers. In particular, the inability of teachers to arrange the appropriate time and environment emerges as an administrative problem. Findings from research (Firat, 2020; Siew et al., 2015) also highlight an issue of infrastructure constraints.

Only three of the teachers included in the school activities were able to complete their implementations. Badley (2009) also stated in his research that concerns about the implementation of the integration of disciplines are a problem in teacher education. According to the results of the research, the teachers stated that although they consider STEM studies valuable, they face implementation barriers. They need support for teachers to do STEM activities (Margot \& Kettler, 2019). 
As a summary, although teachers have hesitations about implementing STEM activities in classrooms; they think that these implementations will make a significant contribution to students about the "skills" students will acquire, the dimension of knowledge they will gain about STEM activities, and the acquisitions of students regarding the learning process.

\section{CONCLUSION}

The participants' thoughts on the outcomes of STEM training on students' skills are teamwork, hand skills, design skills, problem-solving skills, research and questioning skills. In terms of knowledge, it was emphasized that they will learn the project subjects and also enable learning by doing and experiencing cooperation, in which social skills will develop.

The main problems encountered in the in-school implementation of STEM education are the time problem and lack of material, lack of infrastructure, not being able to arrange the appropriate time and environment. Also, crowded classrooms, students' readiness levels, teachers' workload and pressure to finish the curriculum are accepted as barriers to implementing STEM activities.

\section{Recommendations}

Suggestions have been made for researchers who want to develop in-service training on STEM. In this study, in-service STEM approach and school reflections were examined. Data on their own statements were collected from teachers in the evaluation of in-service training. At the stage of evaluating in-service training, the results can be compared by conducting a study with different models (such as expert evaluation) and different data sources (such as in-class observation, video recording). In the process of implementations of STEM approach in school, data can be collected from students and their effects on students' perception, attitude and academic achievement can be predicted. In this context, a contribution can be made to the literature by using different measurement tools. An online platform can be used to support teachers by an expert team in the teacher monitoring and in-school implementation process. In order to popularize STEM approach, a social media page can be created where teachers from different branches can communicate with each other, exchange materials, and create a professional learning community.

For practitioners who intend to spread STEM practice in schools, they must first solve the problems that teachers see as obstacles. In addition, teachers should be provided with material and school practices should be included.

\section{Limitations}

The main limitations of the study are that teachers' opinions are obtained through a questionnaire and that they work with a small sample. In addition, the inability to measure the effects on students as a result of school practices can be seen as a limitation. Also, it is another limitation that there is no data from the implications of teachers in their school.

\section{ACKNOWLEDGEMENTS}

The funding of projects involving this study was provided by the University of Gaziantep Scientific Research Projects (SRP) Management Department.

\section{REFERENCES}

Akgündüz, D., Aydeniz, M., Çakmakçı, G., Çavaş, B., Çorlu, M. S., Öner, T., \& Özdemir, S. (2015). STEM Eğitimi Türkiye Raporu “Günün Modası mı Yoksa Gereksinim mi?"[Turkey STEM Education Report: "The fashion or requirements of the day?"] (D. Akgündüz \& H. Ertepınar (eds.)). İstanbul Aydı Üniversitesi. https://doi.org/10.13140/RG.2.1.1980.0801

Altan, E. B., Ozturk, N., \& Turkoglu, A. Y. (2018). Socio-Scientific Issues as a Context for STEM Education: A Case Study Research with Pre-Service Science Teachers. European Journal of Educational Research, 7(4) 805-812. https://doi.org/10.12973/eujer.7.4.805

Aşık, G., Doğança Küçük, Z., Helvacı, B., \& Çorlu, M. S. (2017). Integrated teaching project: A sustainable approach to teacher education. Turkish Journal of Education. 6(4), 200-215 https://doi.org/10.19128/turje.332731

Bakırcı, H., \& Kutlu, E. (2018). Determination of science teachers' views on STEM approach. Turkish Journal of Computer and Mathematics Education, 9(2), 367-389. https://doi.org/10.16949/turkbilmat.417939

Bayazit, N. T., Akaygün, S., Demir, K., \& Tutak, F. T. (2018). Bir STEM Öğretmen Eğitimi Örneği: Yenebilir Arabalar Etkinliğinin Öğretmen Eğitimi Açısından İncelenmesi [An Example of STEM Teacher Professional Development: Exploration of Edible Cars Activity from Teacher Education Perspective]. Fen Bilimleri Öğretimi Dergisi, 6(2), 213-232. ISSN: 2148-2160.

Bybee, R. W. (2010). The Teaching of Science: 21st-Century Perspectives. National Science Teachers Association. https://doi.org/10.2505/9781936137053

Changtong, N., Maneejak, N., \& Yasri, P. (2020). Approaches for Implementing STEM (Science, Technology, Engineering; Mathematics) Activities among Middle School Students in Thailand. International Journal of Educational Methodology, 6(1), 185-198. https://doi.org/10.12973/ijem.6.1.185 
Cotabish, A., Dailey, D., Robinson, A., \& Hughes, G. (2013). The Effects of a STEM Intervention on Elementary Students' Science Knowledge and Skills. School Science and Mathematics, 113(5), 215-226. https://doi.org/10.1111/ssm.12023

Çorlu, M. S., Capraro, R. M., \& Capraro, M. M. (2014). Introducing STEM Education: Implementations for Educating Our Teachers For the Age of Innovation. Eğitim ve Bilim, 39(171), 74-85. Retrieved from http://hdl.handle.net/11693/13203

English, Lyn D. (2016). STEM education K-12: perspectives on integration. International Journal of STEM Education, 3(1), 1-8. https://doi.org/10.1186/s40594-016-0036-1

Ergün, A., \& Külekci, E. (2019). The Effect of Problem Based STEM Education on the Perception of 5th Grade Students of Engineering, Engineers and Technology. Pedagogical Research, 4(3). em0037. https://doi.org/10.29333/pr/5842

Eroğlu, S., \& Bektaş, O. (2016). STEM Eğitimi Almış Fen Bilimleri Öğretmenlerinin STEM Temelli Ders Etkinlikleri Hakkındaki Görüşleri [Ideas of Science Teachers took STEM Education about STEM based Activities]. Eğitimde Nitel Araştırmalar DergisiENAD Journal of Qualitative Research in Education-JOQRE Eğitimde Nitel Araştırmalar Dergisi-Journal of Qualitative Research in Education, 3(3), 43-67. https://doi.org/10.14689/issn.2148-2624.1.4c3s3m

Firat, E. A. (2020). Science, Technology, Engineering, and Mathematics Integration: Science Teachers' Perceptions and Beliefs. Science Education International, 31(1), 104-116. https://doi.org/10.33828/sei.v31.i1.11

Gunawan, S., \& Shieh, C. J. (2020). Effects of the implementation of stem curriculum integration model to living technology teaching on business school students' learning effectiveness. Contemporary Educational Technology, 12(2), 1-7. https://doi.org/10.30935/cedtech/8583

Jerald, Craig D. (2009). Defining a 21 st century education. The Center for Public Education. http://citeseerx.ist.psu.edu/viewdoc/download?doi=10.1.1.460.8011\&rep=rep1\&type=pdf

Jesionkowska, J., Wild, F., \& Deval, Y. (2020). Active learning augmented reality for steam education-a case study. Education Sciences, 10(8), 1-15. https://doi.org/10.3390/educsci10080198

Landicho, C. J. B. (2020). Research Attitudes, Motivations, and Challenges of STEM Education Researchers. International Journal of Technology in Education, 3(1), 49-61. https://doi.org/10.46328/ijte.v3i1.21

Levy, F., \& Murnane, R. J. (2004). The new division of labor: How computers are creating the next job market. Princeton University Press. ISBN=0-691-11972-4

Madani, R. A. (2020). Teaching Challenges and Perceptions on STEM Implementation for Schools in Saudi Arabia. European Journal of STEM Education, 5(1), 03. https://doi.org/10.20897/ejsteme/8468

Margot, Kelly C., \& Kettler, Todd (2019). Teachers' perception of STEM integration and education: a systematic literature review. International Journal of STEM Education, 6(2).1-16. https://doi.org/10.1186/s40594-018-0151-2

Siew, N. M., Amir, N., \& Chong, C. L. (2015). The perceptions of pre-service and in-service teachers regarding a project-based STEM approach to teaching science. SpringerPlus, 4(1), 17-20. https://doi.org/10.1186/2193-1801-4-8

Siregar, N. C., Rosli, R., Maat, S. M., \& Capraro, M. M. (2019). The Effect of Science, Technology, Engineering and Mathematics (STEM) Program on Students' Achievement in Mathematics: A Meta-Analysis. International Electronic Journal of Mathematics Education, 1(1), 1-12. https://doi.org/10.29333/iejme/5885

Smyrnova-trybulska, E., Morze, N., Kommers, P., Zuziak, W., \& Gladun, M. (2016). Educational robots in primary school teachers' and students' opinion about STEM education for young learners. In Proc. of International Conferences ITS, ICEduTech and STE 2016, 197-204. www.roboty.bielsko.pl

Şahin, A., Ayar, M. C., \& Adiguzel, T. (2014). Fen, teknoloji, mühendislik ve matematik içerikli okul sonrasi etkinlikler ve öğrenciler üzerindeki etkileri [After-school activities with science, technology, engineering and mathematics content and their effects on students]. Kuram ve Uygulamada Egitim Bilimleri, 14(1), 297-322. https://doi.org/10.12738/estp.2014.1.1876

Taştan Akdağ, F., \& Güneş, T. (2017). Science high school students and teachers' opinions about The STEM Implementations on the subject of energy. International Journal of Social Sciences and Education Research, 3(5 S), $1643-1656$. https://doi.org/10.24289/ijsser.337238

Thibaut, L., Ceuppens, S., De Loof, H., De Meester, J., Goovaerts, L., Struyf, A., Boeve-de Pauw, J., Dehaene, W., Deprez, J., De Cock, M., Hellinckx, L., Knipprath, H., Langie, G., Struyven, K., Van de Velde, D., Van Petegem, P., \& Depaepe, F. (2018). Integrated STEM Education: A Systematic Review of Instructional Practices in Secondary Education. European Journal of STEM Education, 3(1), 1-12. https://doi.org/10.20897/ejsteme/85525

Tunç, Cevdet. (2019). Stem: Bütünleşik öğretmenlik çerçevesine yönelik hizmet içi eğitim programının uygulanması ve değerlendirilmesi [The implementation and evaluation of an in- service training program for Stem: Integrated teaching framework]. Unpublished Dissertation. Gaziantep University. Educational Science Institution.

Weintrop, D., Beheshti, E., Horn, M., Orton, K., Jona, K., Trouille, L., \& Wilensky, U. (2016). Defining Computational Thinking for Mathematics and Science Classrooms. Journal of Science Education and Technology, 25(1), $127-147$. https://doi.org/10.1007/s10956-015-9581-5

Windschitl, M. (2009). Cultivating 21st Century Skills in Science Learners: How Systems of Teacher Preparation and Professional Development Will Have to Evolve. In National academies of science workshop on 21st century skills.

Woodside, A. G. (2010). Case Study Research: Theory, Methods, Practice. Emerald Group Publishing Limited.

Wyss, V. L., Heulskamp, D., \& Siebert, C. J. (2012). Increasing middle school student interest in STEM careers with videos of scientists. International Journal of Environmental and Science Education, 7(4), 501-522. 
Yıldırım, B., \& Altun, Y. (2015). STEM Eğitim ve Mühendislik Uygulamalarının Fen Bilgisi Laboratuar Dersindeki Etkilerinin Incelenmesi [Investigation of the Effects of STEM Education and Engineering İmplementations in the Science Laboratory Course]. El-Cezerî Journal of Science and Engineering, 2(22), 28-40.

\section{APPENDIX 1}

\section{STEM Training In-School Implementation Evaluation Questionnaire}

1. Have you made any attempt to prepare a STEM lesson plan and to implement it in the classroom?

If your answer is "Yes", please fill in Part I, if "No", Go to the section and fill in Part II.

Yes (), Part I

2. Have you completed the implementation?

3. What STEM Lesson Plan activities did you do? Can you summarize their names and contents?

4. What kind of problems did you encounter during the implementation? Please explain in detail (AdministrativeAdministrative, Material, Student Status).

5. Did you get support from the project team for the problems you encountered in the implementation? What subject did you get support? Have your problems been solved?

6. What do you think about the implementation of STEM education in your school and classroom conditions?

7. What was the contribution of the project team to the implementation of STEM in school?

\section{No (), Part II}

8. What are the main reasons for not practicing or not?

9. What kind of troubles did you encounter?

10. Do you want support from the Project Team? Has a solution been found? 